\title{
Lateness Attitude among Public Sector Employees in Jakarta
}

\author{
Yurnalis $^{1}$, Debora E. Purba ${ }^{2}$, Dyah T. Indirasari ${ }^{3}$ \\ Faculty of Psychology, Universitas Indonesia, Depok, Indonesia \\ $\left\{{ }^{1}\right.$ yurnalisnita2008@gmail.com, ${ }^{2}$ eflina@ui.ac.id, ${ }^{3}$ dyahti@ui.ac.id\}
}

\begin{abstract}
This study aims to examine the role of work engagement as a mediator in the relationship between future time perspective (FTP) and lateness attitude. We draw on Conservation of Resource theory to explain the relationship. Data were collected from civil servants working in two health facilities owned by one local government. Results showed that work engagement partially mediated the relationship between future time perspective and lateness attitude. The results of this study can be used as an input for companies to increase work engagement level, specifically by enabling supervisors to coach their subordinates to focus on plans and future goals and to keep rehearsing the goals and plans to enhance their future time perspective. The theoretical and practical implications of the findings are then discussed.
\end{abstract}

Keywords: Lateness Attitude, Engagement, Relationship

\section{INTRODUCTION}

Lateness is the most common problematic behavior of people in many developing, equatorial countries with polychronic culture, such as Indonesia[1][2]. Previous research showed around 20-30\% lateness occurred in Indonesian organizations[3][4]. Lateness phenomenon occurred in almost all aspects of community life, affecting the productivity and economy of a country [5][6]. In organizations that provide public services, discipline, one of the indicators is to arrive on time, is a very important factor in supporting service performance [7]. Employee lateness may affect the quality or quantity of services offered, especially when co-workers or consumers rely directly or indirectly on the employee's presence. In addition to influencing the economy, lateness has a psychological impact on other co-workers [5]. The study found that lateness would lead to unfair feelings, resulting in demotivation for other coworkers [8][5].

The researcher found that lateness attitude was a strong predictor of lateness behavior, in which lateness attitude explained the incremental variance of lateness behavior above [8]. Lateness attitude is defined as an attitude that shows one's feelings and thoughts about lateness in the workplace [8]. According to Foust et al. [8], one's attitude toward lateness is influenced by previous experience with his or her own lateness behavior, one's experience with the behavior of others' lateness, and one's belief or cognition of lateness coming to the workplace in general.

Lateness attitude is thought to be related to the way a person perceives time (time perspective) [2]. Zimbardo and Boyd[2] defined time perspective as the unconscious process 
of personal and social experiences placed in the temporal category which helps individuals to give orders, relationships, and meanings for certain events. Each holds five temporal zones to some extent, namely past-negative, past-positive, present-hedonistic, present-fatalistic, and future time perspectives. Past negative describes the pessimistic and negative views of the past. Past-positive reflects the warm and romantic outlook of the past. The hedonistic encompasses life in moments, seeking pleasure, and momentary satisfaction. Present-fatalistic reflects the despair of the future and the inability to connect current behavior with future consequences. Future time perspective shows attention to goal achievement, delayed gratification, and avoidance of wasted time. Individuals with future orientation tend to have high self-regulation and intrinsic motivation, and this would contribute to their ability to select and pursue goals, and in turn their work performance. People with high future time perspective will tend to appreciate the time, which will positively affect task completion before deadlines [9]. Furthermore, Individuals with strong future time perspective tend to engage in forward-looking behaviors, namely planning and avoiding procrastination [9].

In this study, we argue that work engagement would mediate future time perspective and lateness attitude relationship. Work engagement is defined as a positive psychological state of mind and atmosphere of work characterized by vigor, dedication, and absorption towards the work [10]. Previous studies showed a positive correlation between future time perspective and work engagement [11], psychological capital (optimist) which is a similar variable with FTP has a positive correlation with work engagement[12], and a negative correlation between work engagement and lateness attitude [11]. Karatepe and Avci[10] found that work engagement mediated the relationship between psychological capital and lateness attitude. Thus, we believe that work engagement is more proximal to the lateness attitude compared to other variables.

We draw onConservationofResources theory (COR theory) [13]to explain the mediating effect of work engagement on future time perspective-lateness attitude relationship. COR theory explains that every individual seeks to obtain, maintain, and protect the resources they have, and invest them in getting more resources. Based on COR theory, individuals with highlevels of FTP tend to positively think about the future, have clear future goals and plan accordingly to achieve the goals, and these characteristics may serve as resources for individuals to engage in their work by spending more time to focus on their job[11], and improving their performance[14]. Being engaged in the job, in turn, will lead individuals to appreciate the time and avoid coming to work late. To our knowledge, we are one of the first studies to examine the underlying mechanism of future time perspective lateness attitude base on COR theory. Based on the above argumentation and the previously discussed studies, we propose the following hypothesis: "Work engagement mediates the relationship between future time perspective and lateness attitude".

\section{LITERATURE REVIEW}

Participants were civil servant employees between 21-55 years old working in 2 Public Health Centers within the health office of DKI Jakarta Province. The participants followed the study voluntarily by first filling out the informed consent. We ensured that their participation was voluntary, anonymous, and confidential.Ofthe 300 distributed questionnaires, 216 were returned (response rate $=72 \%$ ). Participants consisted of $30.1 \%$ male and $69.9 \%$ female. Participants' mean age was 33.52 years $(S D=9.12)$, with an average working period of 7.29 years $(S D=8.27)$. Participants' educational attainment levels varied,with $40.7 \%$ holding an 
associate degree, 35.2\% had an undergraduate degree, $22.2 \%$ completed senior high schools, $0.9 \%$ held a post-graduate degree, and $0.9 \%$ completed junior high school.

Future time perspective (FTP) was measured using 11 items Zimbardo Time Perspective Inventory (ZTPI)[2]. Work engagement was measured using nine items Utrecht Work Engagement Scale (UWES)-9 [15]. Lateness attitude was measured using a 9-item scale composed by Foust, Elicker, and Levy (2006). The control variables in this study were age, tenure, sex, and education level. Research conducted by Akgeyik [16], showed these variables affect the lateness attitude in both the private and public sectors. Other studies showed that tenure had a positive influence on work engagement [17]. We performed confirmatory factor analysis on LISREL 8.80to test the discriminant validity of the measures, and we tested the hypothesis using Hayes Process Macro on software IBM SPSS software.

\section{RESULT AND DISCUSSION}

We compared the proposed three-factor model (future time perspective, work engagement, and lateness attitude as latent variables) with four theoretically appropriate alternative models, namely 1) a one-factor model in which all indicators were allowed to load into a latent variable, 2) a five-factor model in which future time perspective, lateness attitude, and the three dimensions of work engagement (vigor, dedication, and absorption) acted as latent variables, 3) a five-factor model, where future time perspective, work engagement, and the three dimensions of lateness attitude (latent attitude and cognitions concerning lateness) served as latent variables, and 4) a seven-factor model in which future time perspective, threedimensional work engagement, and three-dimensional lateness attitude were considered a latent variables. The CFA results showed that the three-factor model (future time perspective, work engagement, and lateness attitude) had a better level of fit than the other four alternative models. This indicates that the three variables had acceptable discriminant validity.

The average variance of extract (AVE) for future time perspective, work engagement, and lateness attitudes were 0.97, 0.63, and 0.49, respectively. Although Ave's lateness attitude was only 0.49 , the loading factor for lateness attitude was significant. While the reliability Chronbach' Alpha of future time perspective, work engagement, and lateness attitude were $0.64,0.90$ and 0.77 , respectively (table 1 ). All variables were reliable because the Chronbach's Alpha of each variable passes 0.60 .

Table 1. Summary of Statistics and Correlations Among Variables.

\begin{tabular}{|c|c|c|c|c|c|c|c|c|c|c|c|}
\hline & Variables & Mean & $S D$ & $A V E$ & 1 & 2 & 3 & 4 & 5 & 6 & 7 \\
\hline $\begin{array}{l}1 . \\
2 . \\
3 . \\
4 . \\
5 .\end{array}$ & $\begin{array}{l}\text { Age } \\
\text { Gender } \\
\text { Education } \\
\text { Tenure } \\
\text { Future Time } \\
\text { Perspective } \\
\text { Work } \\
\text { Engagement } \\
\text { Lateness } \\
\text { Attitude }\end{array}$ & $\begin{array}{c}33.52 \\
1.70 \\
4.13 \\
7.29 \\
3.80 \\
4.68 \\
2.67\end{array}$ & $\begin{array}{l}9.12 \\
.46 \\
.79 \\
8.27 \\
.36 \\
.86 \\
.75\end{array}$ & $\begin{array}{l}- \\
- \\
- \\
- \\
.97 \\
.63 \\
.49\end{array}$ & $\begin{array}{c}- \\
-.119 \\
-.128 \\
.732^{* *} \\
-.073 \\
.051 \\
.101\end{array}$ & $\begin{array}{c}- \\
.120 \\
.030 \\
.011 \\
.055 \\
.140^{*}\end{array}$ & $\begin{array}{c}- \\
-.074 \\
.222^{* *} \\
.124 \\
-.007\end{array}$ & $\begin{array}{c}- \\
- \\
.053 \\
.046 \\
.018\end{array}$ & $\begin{array}{l}(.64) \\
.343^{* *} \\
-.247^{* *}\end{array}$ & $\begin{array}{c}(.90) \\
- \\
.365^{* *}\end{array}$ & $(.77)$ \\
\hline
\end{tabular}


Note. $\mathrm{N}=216 . \mathrm{SD}=$ Standart Deviation. $\mathrm{AVE}=$ Average Variance of Ektract $* \mathrm{p}<.05, * *$ $\mathrm{p}<.01$

Table 1 shows the means, standard deviations, averagevariance of extract, Cronbach alphas and correlations among research variables. The correlation analysis showed that gender is significantly correlated with lateness attitude $(r=.14, p<.05)$, but lateness attitude has no significant correlation with age $(r=-.10, p>.05)$, education $(r=-.007, p>.05)$, or tenure $(r$ $=.018, p>.05)$. Moreover, future time perspective significantlyand positivelycorrelated with work engagement $(r=.34, p<.01)$ and significantly and negatively correlated with lateness attitude $(r=-.25, p<.01)$. The results also showed that work engagement significantly and negatively correlated with lateness attitude $(r=-.37, p<.05)$.

Our hypothesis states that work engagement mediates the relationship between future time perspective and lateness attitude was supported by our data. Our results showed that work engagement indeed mediated the relationship between future time perspective and lateness attitude (indirect effect $=-22, S E=.062,95 \%$ CI [-.0062, - 1143]), supporting our hypothesis. However, work engagement only partially mediated the relationship between future time perspective and lateness attitude (figure 1), as the direct effect between future time perspective and lateness attitude was still significant after controlling for work engagement (direct effect $=$ $-0.28, S E=.14, p<.05)$.

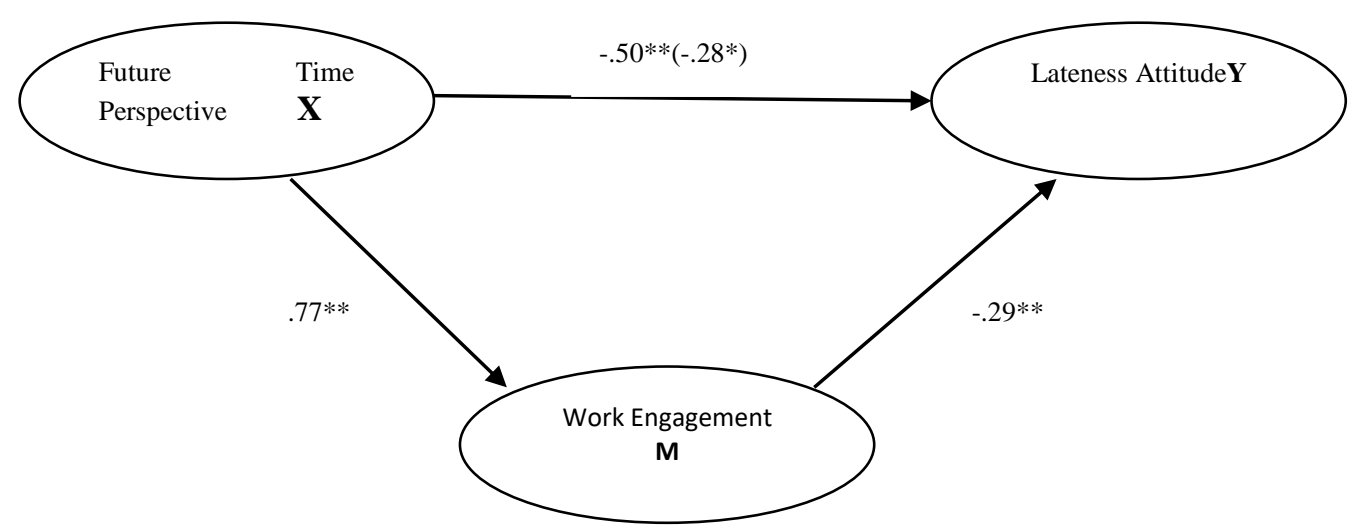

Figure 1. Effect of Future Time Perspective on Lateness Attitude Through Work Engagement.

Note: $\mathrm{N}=216 . * \mathrm{p}<.05, * * \mathrm{p}<.01 * *$. Coefficient between the brackets is the direct effect.

This study is among the first studies to use COR theory as a framework for studying future time perspective-lateness attitude relationship. This study contributes to the literature by showing work engagement as one underlying mechanism that helps explain the relationship between future time perspective and lateness attitude. Previous research conducted by Karatepe and Avci[18] used the J-DR framework in explaining the relationship between the mentioned variables.

However, it is important to note that we only found partial mediation of work engagement, indicating that there is some variance of outcome that can be explained by independent variable but not by intervening variable[19]. We assume that the variance related to planning future goals in future time perspective accounted for the variance in lateness attitude, but is unlikely to account for the variance in work engagement variable, considering that work engagement indicates in-the-moment enjoyment of working. According to Díaz and 
Ferrari[20], Individuals with high future time perspective tend to be careful in planning and managing their activities. Consequently, they will display discipline, ability to manage time and systematic work ability [20]. Our results are consistent with previous research that examined the mediating role of work engagement in lateness attitude [18]. In other word individuals with high future time perspective are more engaged with their work and more likely to display lower lateness attitude.

Organizations may benefit from taking the results of this study in consideration during the recruitment and selection of employees. In the recruitment process, we advise companies to assess the time perspective of prospective employees to be selected. Prospective employees with high future time perspective are valuable assets that need to be prioritized in employee selection. The results of this study can also be used as an input for companies to increase work engagement level, specifically by enabling supervisors to coach their subordinates to focus on plans and future goals and to keep rehearsing the goals and plans to enhance their future time perspective.

This research has several limitations that need to be discussed. First, this study was conducted only in two healthcare organizations in one municipal area, which poses a problem for the generalizability of the research results. In future studies, we suggest that researchers replicate the study using other populations, such as employees of private organizations or other professions. Second, this study employed a cross-sectional design that prevented us from confirming the causal relationship between our research variables. Longitudinal research would need to be done in the future to determine whether future time perspective is a stable individual characteristic and whether a causal relationship between the study variables exists. Third, data were obtained using the only self-report method, therefore raising the possibility of common method bias [21]. Furthermore, the self-report method has the potential of being influenced by a social desirability bias. While we believe that the self-report method is the best method to assess individuals' future time perspective, work engagement, and lateness attitude variables, we suggest future researchers to employ temporal separation in collecting the predictor, mediator, and outcome variables, or to use diary study to consider the fluctuations of the levels of the variables over time[21].

\section{CONCLUSION}

This research found that work engagement served as an underlying psychological process that helps explain the relationship between future time perspective and lateness attitude. As there is still a lack of research on the relationship between future time perspective and lateness attitude, we suggest there be more extensive research in the area to further examine the possible mediating and moderating roles of variables.

\section{ACKNOWLEDGEMENT}

This work is supported by Hibah PITTA 2018 funded by DRPM Universitas Indonesia No. 2347/UN2.R3.1/HKP.05.00/2018.

\section{REFERENCES}

[1] C. A. Fulmer, B. Crosby, and M. J. Gelfand, "Cross-cultural perspectives on time," Time Work, vol. 2, pp. 53-75, 2014.

[2] P. G. Zimbardo and J. N. Boyd, "Putting time in perspective: a valid, reliable 
individual differences metric,” J. Pers. Soc. Psychol., vol. 6, no. 77, pp. 1271-1288, 1999.

[3] F. Akbar, "Pengaruh insentif terhadap loyalitas kerja karyawan bank BRI wilayah kerja Pekan baru," J. Online Mhs. Bid. Ilmu Sos. dan Ilmu Polit., vol. 4, no. 1, pp. 113, 2017.

[4] L. N. Suryani, "Pengaruh disiplin kerja terhadap kinerja pegawai kipp teknologi aplikasi produk ppptmgb lemigas jakarta selatan,” J. Kreat., vol. 6, no. 2, pp. 1-17, 2018.

[5] V. K. Sapovadia, "Global Punctuality Index: A Tool to Save Trillion Man Hours," SSRN Electron. J., 2014.

[6] M. Koslowsky, Voluntary employee withdrawal and inattendance, 1st ed., no. July 2011. New York: Springer Science+Business Media New York, 2002.

[7] A. Pangarso and P. I. Susanti, "Pengaruh disiplin kerja terhadap kinerja pegawai di biro pelayanan sosial dasar sekretariat daerah provinsi Jawa Barat," J. Manaj. Teor. dan Terap. Tahun, vol. 9, no. 2, pp. 145-160, 2016.

[8] M. S. Foust, J. D. Elicker, and P. E. Levy, "Development and validation of a measure of an individual's lateness attitude," J. Vocat. Behav., vol. 69, no. 1, pp. 119-133, 2006.

[9] P. G. Zimbardo and J. N. Boyd, The time paradox: The new psychology of time that will change your life. New York: Free Press, 2009.

[10] W. B. Schaufeli, M. Salanova, V. G. Roma, and A. B. Bakker, "The measurement of engagement and burnout: a two sample of confirmatory factor analytic approach.," $J$. Happiness Stud., vol. 3, no. 1, pp. 71-92, 2002.

[11] S. K. Sia, B. C. Sahoo, and P. Duari, "Gender discrimination and work engagement: Moderating role of future time perspective," South Asian J. Hum. Resour. Manag., vol. 2, no. 1, pp. 58-84, 2015.

[12] D. A. S. Nugroho, E. Mujiasih, and U. Prihatsanti, "Hubungan antara psychological capital dengan work engagement pada karyawan pt. bank mega regional area semarang," J. Psikol. Undip, vol. 12, no. 2, pp. 191-202, 2013.

[13] S. E. Hobfoll, "Conservation of resources: A new attempt at conceptualizing stress," Am. Psychol., vol. 44, no. 3, pp. 513-524, 1989.

[14] N. Damayanti and M. Tjendana, "Hubungan motivasi kerja dan keterlibatan kerja dengan kinerja," J. Anal., vol. 4, no. 1, pp. 31-37, 2012.

[15] A. B. Bakker, W. B. Schaufeli, A. B. Bakker, and M. Salanova, "The measurement of short questionnaire a cross-national study," Educ. Psychol. Meas., vol. 66, no. 4, pp. 701-716, 2006.

[16] T. Akgeyik, "Predictors of employee lateness (analysis of data from a waste management company)," Int. J. Bus. Res., vol. 16, no. 4, pp. 130-137, 2016.

[17] I. D. Kurniawati, "Masa kerja dengan job engagement pada karyawan," J. Ilm. Psikol. Terap., vol. 2, no. 2, pp. 311-321, 2014.

[18] O. M. Karatepe and T. Avci, "The effects of psychological capital and work engagement on nurses' lateness attitude and turnover intentions," J. Manag. Dev., vol. 36, no. 8, pp. 1029-1039, 2017.

[19] A. F. Hayes, Introduction to mediation, moderation, and conditional process analysis: A regression-based approach. NewYork: The Guilford Press, 2013.

[20] M. Stolarski, N. Fieulaine, and W. van Beek, Time Perspective Theory; Review, Research and Application, no. January. Cham: Springer International Publishing, 2015.

[21] P. M. Podsakoff, S. B. MacKenzie, J. Y. Lee, and N. P. Podsakoff, "Common method 
biases in behavioral research: A critical review of the literature and recommended remedies," J. Appl. Psychol., vol. 88, no. 5, pp. 879-903, 2003. 